Volume 3

Issue 1 :Conflict Prevention \& Management

Article 4

August 2016

\title{
China and Africa's Peace and Security Agenda: The Burgeoning Appetite
}

\author{
Oita Etyang \\ University of Johannesburg, oetyang@comesa.int \\ Simon Oswan Panyako \\ University of Nairobi, soswan@comesa.int
}

Follow this and additional works at: https://digitalcommons.usf.edu/jacaps

Part of the African Studies Commons, Arts and Humanities Commons, Defense and Security Studies Commons, Economic Policy Commons, Emergency and Disaster Management Commons, International Relations Commons, Military and Veterans Studies Commons, Peace and Conflict Studies Commons, and the Public Policy Commons

\section{Recommended Citation}

Etyang, Oita and Oswan Panyako, Simon (2016) "China and Africa's Peace and Security Agenda: The Burgeoning Appetite," Journal of African Conflicts and Peace Studies: Vol. 3: Iss. 1, . DOI: http://dx.doi.org/10.5038/2325-484X.3.1.1085

Available at: https://digitalcommons.usf.edu/jacaps/vol3/iss1/4

This Article is brought to you for free and open access by the Open Access Journals at Digital Commons @ University of South Florida. It has been accepted for inclusion in Journal of African Conflicts and Peace Studies by an authorized editor of Digital Commons @ University of South Florida. For more information, please contact digitalcommons@usf.edu. 


\section{China and Africa's Peace and Security Agenda: The Burgeoning Appetite}

\section{Cover Page Footnote}

Oita Etyang is a PhD student at the University of Johannesburg in the Department of Politics and International Relations. Currently Works at COMESA Secretariat as an analyst - Governance Peace and Security Simon Panyako Oswan is a PhD student at the University of Nairobi - Institute of Diplomacy and International Studies (IDIS). Currently Works at COMESA Secretariat as an M and E expert 


\section{Introduction}

The rising hegemony of China in the international geo-politics has left an indelible mark on Africa's economic development. Undeniably, China's umbilical tie with Africa has been shaped by colonial struggles of 1950's and the South-South camaraderie espoused by Chairman Mao Tse Tung in the 1950s and 1960s. The ever-increasing China's interests in Africa in the $21^{\text {st }}$ century has been embraced with much gusto by many African leaders as an opportunity to instigate economic "takeoff", to leverage their bargaining power with traditional western donors and to amplify Africa's voice in international platforms. It suffices to note that China's engagement has mostly been amplified in the economic and infrastructure sectors with dearth postulations in the area of peace and security. With China's growing role in the United Nations Security Council, coupled with continued protracted conflicts in Africa - Somalia, Sudan, South Sudan, the Democratic Republic of Congo (DRC), Central African Republic (CAR), Libya and the escalation of transnational crimes such as terrorism and piracy, China has tended to shift from its traditional principle of non-interference or what we call "no-strings attached" kind of engagement to a more "strings attached engagement" with African states. This shift has been more prominent in the area of peace and security.

It is premised on this covert shift that this paper interrogates China's role in Africa's peace and security agenda. Country examples are elucidated. Reasons for China's appetite for issues of peace and security are also dealt with. The main thesis in this article is that China's burgeoning appetite is not designed to promote peace and security in Africa but to secure state interest - hegemony in global politics, economic expansion and prestige that go hand-in-glove as world power. The article aims at contributing to peace, security and conflict literature by examining China's involvement in Africa's peace and security agenda. The paper draws upon existing literature - books, monographs journal articles, organizational and media reports. Authors' experiences on issues of peace and security in Africa are also used to buttress the discourse on the issue area.

\section{China and Africa: The Historical Umbilical Ties}

The congenial ties between China and Africa have thrived for ages. The ties blossomed with the advent of the cold war and liberation struggles in 1950s. During this historical epoch, the SinoAfrican political relations were cemented by ideological struggles against the hegemons, specifically, to neutralise America and Soviet influence in Africa (Van de Looy, 2006: 2). Undeniably, the Bandung conference of April 1955 that roped together the non-alignment group from Asia and Africa redefined the political ties. The meeting underscored the importance of forging common economic and cultural ties between China and African states.

Buoyed by common interests and the emerging dynamics in international relations, the SinoAfrican relations have speedily morphed. China's policy shift has undoubtedly played its role in this respect. During his sojourn to Africa in 1963-64, Premier Chou enumerated five principles on which China's relations with African countries were based. He also expounded on the eight principles, which China must adhere to in rendering economic and technical aid to African countries (Jinyuan, 1984: 248). After nearly two decades, the spirit as well as the wording still stand, but some slight modifications have been made in light of the prevailing realities brought 
about by globalisation. From our observation with regard to China's policy towards Africa, we submit that China has acted on the following principles:

1. Support African people in their struggle for independence and safeguard their national sovereignty against colonialism, imperialism, and neo-imperialism;

2. Establish and enhance reciprocal ties with Africa on the basis of equality, mutual benefit and co-operation;

3. Provide Africa with material and technical assistance in accordance with China's ability;

4. Support the African governments in pursuance of a policy of peace, neutrality and non-alignment;

5. Advocate for the resolution of disputes between African countries through peaceful negotiations, upholding of African solidarity, and opposition to aggression and interference by alien forces;

6. Support African countries in their efforts to develop their national economies and seek a new economic world order

Other interlocutors such as Zeleza (2008: 172) postulate that the relationship between China and Africa intensified in 2000 after the first Ministerial Conference of the Forum on China-Africa Cooperation (FOCAC) that was held in Beijing in October. It was attended by the Chinese President and Premier and four African Presidents and the Secretary-General of the Organisation of Africa Unity (OAU), as well as more than 80 ministers from China and 44 African countries, representatives from 17 regional and international organizations, and business people from Africa and China. This was followed by the second ministerial conference in Addis Ababa in December 2003 that was attended by the Chinese Premier, six African Presidents and three Prime Ministers, the heads of the African Union and the United Nations, and more than 70 ministers from China and African countries. In November 2006, came the scintillating Beijing Summit and Third Ministerial Conference of FOCAC, which was attended by the leaders of 48 African countries, from Egypt to South Africa. The summit redefined China relationship with Africa. Since then, China - African ties have continued to be strengthened with many states visits from China and Africa leaders in return making strategic overtures to China.

We argue in this paper that China's newly found affection for Africa is twofold (1) economic and (2) ge-opolitical. According to Taylor (2015), Beijing's economic interests in Africa are based on three factors. First, Beijing asserts that the macroeconomic situation in Africa is taking a favorable turn. This analysis is based on the belief that African countries have adopted a set of active measures to push forward the pace of privatisation, open to international trade, and reform their economies. China believes that these afford them greater economic opportunities. Secondly, Chinese manufacturers and shopkeepers believe that the types of goods they produce and sell have immense potential in Africa. They believe that the economy in Africa is not yet as developed as in western nations and consumers are perceived to be more receptive to the type of inexpensive products that China typically produces. Thirdly, the Chinese government and business moguls look to secure access to Africa's abundant natural resources, particularly crude oil, non-ferrous metals, and fisheries. 
Based on the economic interests or what we refer to as "China-centric" perspective, China has invested heavily in the African continent thus benefiting many families and communities. A review of China's Ministry of Commerce (MOFCOM) data set (2014) indicates that China's Outward Foreign Direct Investment (OFDI) to Africa has been growing exponentially from US \$ 1 billion in 2004 to US $\$ 24.5$ billion in 2013. A large chunk of the money has largely been invested in mining and oil extraction industries. Investments have also been made in infrastructure. In Kenya and Ethiopia for example, China has funded the construction of roads and rail network systems. The data set further indicates that 4 percent of China's OFDI stock equivalent to US \$ 26.2 billion was invested in Africa by the end of 2013. The highest recipients of China's OFDI by 2013 included: South Africa, Angola, Democratic Republic of Congo (DRC), Zambia, Zimbabwe, Sudan, Nigeria and Algeria. Suffice to mention that China's OFDI have also started to trickle to some other countries such as Kenya, Ethiopia and Tanzania, among others. It is apt to mention, in the spirit of reciprocity, that China has also benefited from ties with Africa. China has benefited from Africa's oil and ferrous metals to support its industrial needs. The large consumer market in Africa has also provided the much need market for China. In the realm of peace and security, African countries have assisted China to push through some reform agenda in the United Nations General Assembly. China has in most cases relied on African countries to push its agenda at the United Nations.

In terms of geo-political interests, China seeks to position itself as a hegemon in the international arena. It seeks to position itself as an alternative powerhouse to America that has largely dominated international relations for decades. In other words it aims to tilt the balance of power in global politics. The Pew Global Attitude Survey of 2011 that is cited by Zhou corroborates this viewpoint (2011). According to this survey, the majority of the respondents opined that China was going or had already replaced America as a superpower (Zhou, 2011). The proponents (Kaplan: 2005, Bernstein and Munro: 1997, Mearsheimer: 2011, and Gordon: 2011) of this perspective view China as an emerging imperial power that wants to subvert western influence. They predict a fierce Sino-America competition that will ultimately culminate into war (See Zhou, 2011:628). The proponents of this school of thought view China as an impediment to the core principles of democracy that America has strived to propagate in the world. Thus, by doing so, challenging America's hegemony, the proponents have further questioned China's arms race. To them, China's arms race is aimed at challenging Americas military might not only in Asia but also in other geopolitical regions such as Africa. A more optimistic perspective is being championed that the two countries can coexist in a mutually reinforcing manner thus maximise on their national interest without harming each other. The optimist narrative holds that China and America can prefect the world without stepping on each other's toes.

\section{China's Involvement in Africa's Peace and Security Agenda: A Reflection}

China's role in global peace politics has been transformed in the past two decades. A part from its dominance in the economic pursuit, China has made issues of peace and security part of its foreign policy. It is not by accident that China is now actively engaged in conflict mediation and peace diplomacy in different parts of the world. It is a well-choreographed foreign policy direction that Beijing endeavors to espouse as part of the wider strategies to brand itself as a valuable actor in the effort of building a "harmonious and cohesive" world. Indeed, the $21^{\text {st }}$ Century has seen China evolve from its traditional rhetorical support that was passive on issues of peace and security to 
become a substantive multilateral actor. Since assuming its permanent seat in the United Nations Security Council (UNSC) in 1971 and following the adoption of the open and reform policy in 1978, China has maintained an active role in promoting peace and security despite criticism on some of the decisions it has made within the "body politic" of the UN Security Council.

China's proactive involvement in international peace and security is given impetus by three policy considerations that are in tandem with her national interest. First, as earlier suggested, China aims to boost its image internationally. China is responding to the international obligation of safeguarding world peace. As an emerging hegemonic power, China seeks to demonstrate to the world that it can be relied upon as far as world peace is concerned. Huang and Gill (2009) write "[...] engagement with the outside world helps China project a more benign and harmonious image beyond its boarders[...]" According to them, China's involvement in the world's peace and security agenda "reassure neighbours about its peaceful intentions and softly balances US and western influence while gradually but more firmly establishing China's acceptance as a great power." Second is China's desire to protect its economic investments in the outside world. China has heavily invested in various economic sectors in different parts of the world. In Africa, China has invested heavily in the oil and manufacturing industries, among others. We argue that violent conflicts have threatened China's investments prompting Beijing to proactively prioritise issues of peace and security in its foreign policy. Moumouni (2014: 7) notes that socio-economic development has provided human, material and financial resources for China to engage in peacekeeping operations. Third, and last, participating in peace and security endeavors offers valuable lessons for China in dealing with domestic attrition in their pursuit of development. To offer a possible illustration of this aspect Huang and Gill (2009) argue that deployment of troops, police and experts "provide useful and practical experiences for Chinese security forces and help improve their responsiveness, riot control capabilities of military emergency command systems and ability to conduct military operations other than war."

In Africa, various frameworks under the auspices of FOCAC have been established to guide ChinaAfrica engagement on issues of peace and security. As we have insinuated in the previous section, the frameworks include the Addis Ababa Action Plan of 2003, China's Africa Policy Paper of 2006 that summaries areas of military engagement and the China-Africa Cooperation Beijing Action Plan of 2013 -2015. The Beijing Action Plan emphasis that:

China will launch "Initiative on China-Africa Cooperative Partnership for Peace and Security" and will provide, within the realm of its capabilities, financial and technical support to the African Union for its peace-support operations, the development of the African Peace and Security Architecture (APSA), personnel exchanges and training in the field of peace and security and Africa's conflict prevention, management and resolution and post-conflict reconstruction and development.

The above frameworks embody the nature of China-Africa cooperation on issues of peace and security. Here the question is; how then has China involved itself on issues of peace and security in Africa? A closer look at China's policy papers indicate that China involvement in Africa's peace and security agenda has largely been confined in the UN peacekeeping missions, humanitarian assistances and post conflict reconstruction. A statement in its policy document "Chinas 2008 White Paper on Defense" posits that China has "consistently supported and actively participated 
in the peacekeeping operations in line with the UN Charter." This statement is factual if we examine China's engagement in peacekeeping efforts in the last two decades. According to Bates (2009) China has continued to provide essential material and technical support to peacekeeping missions. They have continued to provide training, engineers, medics and transport logistics when peacekeeping missions are overstretched. In 1989, China participated for the first time in a peacekeeping mission when it deployed 20 Chinese military observers to support the UN Transition Assistance Group that was monitoring elections in Namibia. A cursory survey of peacekeeping data indicates that China by end of May 2015 had contributed a total number of 3,084 (2,875 troops, 176 police and 33 experts) personnel to UN peacekeeping missions all over the world. This is way higher than any of the permanent members of the UN Security Council France 926, Russia 71, United Kingdom 288 and United States 80 personnel. This is summarized in table 1.

Table 1: Personnel Contribution by Permanent Members of UN Security Council

\begin{tabular}{|l|l|l|l|c|}
\hline Country & Troops & Police & Experts & Total \\
\hline China & 2,875 & 176 & 33 & 3,084 \\
\hline France & 878 & 39 & 9 & 926 \\
\hline Russia & 4 & 18 & 49 & 71 \\
\hline United Kingdom & 284 & 4 & 0 & 288 \\
\hline United States & 36 & 39 & 5 & 80 \\
\hline
\end{tabular}

Source: Extrapolated by the authors from UN Peacekeeping Data May, 2015

A further interrogation of UN data indicates that out of the $10 \mathrm{UN}$ missions that China is currently involved, 7 are in Africa. This implies that China has a total number of 2,664 personnel in various missions in Africa comprising of 2,460 contingent troops, 174 police, and 30 experts. The highest personnel are in South Sudan - 1,042 troops and 15 Police followed by Liberia with 564 troops, 159 police, and 2 experts. The stabilisation mission in Mali comes after Liberia with 402 troops.

Table 2: China's Participation in UN Missions in Africa, Number of Troops, Police and Experts

\begin{tabular}{|c|c|c|c|c|}
\hline UN Mission & Acronyms & Troops & Police & Experts \\
\hline $\begin{array}{l}\text { United Nations Mission for the Referendum } \\
\text { in Western Sahara }\end{array}$ & MINURSO & - & - & 10 \\
\hline $\begin{array}{l}\text { United Nations Multidimensional Integrated } \\
\text { Stabilization Mission in Mali }\end{array}$ & MINUSMA & 402 & - & - \\
\hline $\begin{array}{l}\text { United Nations Organization Stabilization } \\
\text { Mission in the DR Congo }\end{array}$ & MONUSCO & 221 & - & 12 \\
\hline $\begin{array}{l}\text { African Union - United Nations Mission in } \\
\text { Darfur }\end{array}$ & UNAMID & 231 & - & - \\
\hline United Nations Mission In Liberia & UNMIL & 564 & 159 & 2 \\
\hline $\begin{array}{l}\text { United Nations Mission in the Republic of } \\
\text { South Sudan }\end{array}$ & UNMISS & 1042 & 15 & - \\
\hline United Nations Operation in Côte d'Ivoire & UNOCI & - & - & 6 \\
\hline Total & & 2460 & 174 & 30 \\
\hline Grand Total & 2664 & & & \\
\hline
\end{tabular}




\section{Source: Extrapolated by the Authors from UN Peacekeeping Data May, 2015}

The South Sudan deployment is a milestone in the history of China in peacekeeping operations. This is premised on the fact that for the first time, China has contributed a combat battalion to the UN peacekeeping mission - it has exported "hard power" to peacekeeping operations. The contingent of 1,042 is well equipped with armored infantry carriers, anti-tank missiles, mortars and drones. The deployment of the contingent is in response to the UN resolution 2155 of 2014 that reiterated the reinforcement of United Nations Mission in the Republic of South Sudan (UNMISS) and protection of the imperiled civilians and the oil fields. Experts argue that China's huge deployment in South Sudan is aimed at protecting its investments in oil industry. Conservative figures indicate that between 2008 and 2013; just before the violence broke out, China and the Government of South Sudan had concluded agreements worth US \$ 10 billion (see Hang, 2014, Aguirre, 2014). The current conflict does not potent well for China's investments thus necessitating a response from Beijing. Indeed, China Foreign Minister Wang Yi has been working in conjunction with western diplomats to end the current South Sudanese political impasse in Addis Ababa - Ethiopia. We submit that China will continue to actively engage in diplomatic exploits to end the conflict in South Sudan. China stands to benefit tremendously if peace is restored in Africa's youngest nation. The involvement of China in South Sudan affirms our earlier assertion that China's involvement in peacekeeping is hitched to its economic interests.

The battlefield of Darfur is another region that China has deployed its service men and women. Currently, it has a total number of 231 contingent troops. Agubama (2014) and Junbo (2012) have considered the Darfur deployment to be laced with controversy based on China's initial stand and hand-in-glove kind of relationship with Khartoum. In the initial stages of the conflict in Darfur, China invoked its traditional mantra of non-interference. They considered the conflict a mundane issue that the sovereign state of Sudan could comfortably deal with without external interference. The non-interference policy was cited despite the fact that two Chinese workers who were drilling a well for the locals had been kidnapped by Sudan Liberation Army (SLA). When the United States planned to sanction Sudan, China argued that Sudan is a sovereign country thus it should be left to deal with its internal challenges. China's position at the time was further strengthened by Sudan's assertion that they were in control of the situation. Beijing position shifted mid-2004 when China's special representative to Darfur Lu Guozeng visited Khartoum and convinced Al Bashir to respect UN resolution and develop a road map towards finding a lasting solution to the problems in Darfur. Towards the end of 2004, Ahmed (2010: 6-7) observes that Chinese officials engaged in shuttle diplomacy with Khartoum urging the government to provide economic security and social assistance to the population in Darfur. With a shift in Beijing position, China started providing sanitation and health amenities like water, electricity and health care services to alleviate the effects of the conflict in Darfur. China has continued to actively support the UN mission in Darfur. It is noteworthy to mention that China, through its envoy Liu Guijin, participated in a peace conference between the Government of Sudan and opposition groups in Darfur that was held in Sirte in 2007. In recognition of Chinas contribution to the peacekeeping mission in Darfur, the UN through Lt. Gen. Patrick Nyamvumba conferred medallions of honour to 315 troops in 2011(See China Military News, 2015).

China's engagement in Liberia followed the adoption of the UN resolution 1509 of (2003). A critical look at the mandate of the United Nations Mission in Liberia (UNMIL) indicates that the 
mission is largely a post conflict reconstruction mission. It is multidimensional in nature bringing under one roof different components including political, military, police, criminal justice, civil affairs, human rights, gender and child protection components. China's peacekeepers in UNMIL are predominantly designated to provide engineering and medical services and also provide transport logistics. Through this mission, China has been able to assist the government of Liberia. It has built infrastructure such as roads, hospitals, and schools among other important social amenities. Ayenagbo et al. (2012) note in their journal paper, that roads and bridges have been named after the Chinese in recognition of their contribution to the reconstruction of Liberia. China has also engaged in humanitarian assistance in Liberia. In the 2014 Ebola epidemic, China sent a team of doctors and health workers to help contain the security threats posed by Ebola. China built a US \$ 41 million Ebola clinic. Reiterating China's commitment ambassador Zhang Yue said "Up to now in Liberia, China is the only country which provides not only the construction of an Ebola Treatment Unit (ETU), but also the running and operation and the staffing of an ETU" (Reuters, 2014). In addition, China contributed US $\$ 6$ million to the World Food Programme (WFP) in the fight against Ebola in Guinea, Liberia and Sierra Leone (World Food Programme, 2014).

In the war against piracy, China has used its maritime capabilities to daunt piracy activities along the Gulf of Aden. The involvement of China in maritime security reflects the naval capabilities of the People's Liberation Army Navy (PLAN). Indubitably, in 2008 China deployed a naval ship with missile destroyers in the Gulf of Aden. The Chinese navy's continued patrol in the Gulf of Aden has deterred pirate attacks. Statistics released by the North Atlantic Treaty Organisation (NATO) in October, 2014 indicate that pirate attacks and hijacks had waned to zero digit as compared to 42 attacks and 33 hijacks in 2008. The economic benefits accrued from the decline have benefited Chinese merchants who transport their goods along that coastal line. It is our assertion that Kenya, Uganda and Rwanda that largely depend on the port of Mombasa, have also benefited from China's overtures along the Gulf of Eden.

Recognising the importance of regional organisations, China has been engaging with the African Union (AU) on issues of peace and security. China has established a dialogue framework with the AU that monitors the peace and security situation in Africa. The engagement of China and AU's Peace and Security Council has gained momentum in the recent past. China has been funding the implementation of some of the AU's Peace and Security Council decisions. For instance, China granted AU funds to facilitate the peace process in Sudan. Currently, it has been supporting AU's efforts in stabilising Somali. At the sub-regional level, China has supported the peace fund of the Economic Community of West African States (ECOWAS). The peace fund is designed to assist ECOWAS to respond to threats to peace and security in the region in a timely manner (African Union, 2010).

\section{Is China's Burgeoning appetite a threat to Africa's Peace and Security?}

Two schools of thoughts have emerged as regards China's increasing engagement on issues of peace and security. The first school dubbed the "China threat theory" emerged in the 1990s when China experienced unprecedented growth and expansion. During this period, China strengthened its military capabilities and revamped its Navy (Ateba, 2002:3). This school of thought is premised 
on the fact that China's growing influence in economic and military sectors was a threat to peace and security not only in Asia but also to other major powers. Ateba (2002: 2-3) in his journal article titled "Is the rise of China A security threat" notes that the expansion is a concern to western powers in that China is becoming a competitor for markets, mineral resources funds and even military capabilities. According to this school of thought, China is to be contained to avert conflicts that arise from competition among nations.

The second school of thought posits that China faces a plethora of internal challenges - corruption, environmental degradation, high population growth, and secessionist pressure in Tibet, Inner Mongolia and Xinjiang (see Ateba, 2002), among others, consequently, it lacks the legitimacy to pose any threats to peace and security. According to this school of thought China is looking outwards to solve some of its domestic challenges. In the case of Africa, it is searching for resources to solve its modernisation quest thus it does not pose any threat to Africa's peace and security. This paper deliberately takes a nihilist view and argues that China has been a conflict driver in Africa. This is discoursed as follows:

\section{Economic Insecurity}

Economic insecurity is anchored in the broader context of human security concept. Specifically, economic insecurity can be conceptualized as the state of being subjected to ill health, malnutrition, unemployment, exploitation by employers and being subjected to indignity of poverty. This conceptualisation sits within the broader context of development as propounded by developmentalist theorists (see for example Grasper and Truong, 2005, Miner, 2007) who argue that provision of health care, employment, decent remuneration are critical for development. A look at China's involvement in Africa, we contend that their involvement has impoverished many Africans. The impact has been more pronounced in the realm of economic security. The economic involvement of China in Africa has led to the flooding of African markets with Chinese goods. China has taken advantage of the laisser-faire economy to flood the market. In fact it is an eyesore to walk in one of the African capitals and what is displayed in shop shelves are all Chinese wear. The resultant effect is that most local industries have been pushed out of the market premised on the fact that they cannot compete favorably with cheap goods from China. The spiral effect has been large-scale unemployment, lack of income and food for many families. Related to this is the fact that most Chinese companies operating in Africa, especially those in infrastructure construction many a times export cheap labour from China. It's a common phenomenon to encounter large contingents of Chinese labourers in construction sites. The implication is that there is unfavorable job competition with the local population that is largely unemployed. This has caused resentments within local communities. To compound the problem further, Chinese nationals have been running small-scale shops in various towns in Africa thus denying the locals the opportunity to make a living.

In Malawi for example, Chinese-owned shops and restaurants proliferated forcing many local small owners out of business. This prompted the government of Malawi to enact legislation preventing foreign traders from operating outside the major cities. This scenario is captured by a vendor in Lesotho who opines "Chinese are now selling makoenya [fat cakes], loose cigarettes, even beer at retail prices, but their business category forbids them from doing so," (see IRI News, 2015). In Zambia, resentment against Chinese investment led to a violent protest in Chambisi copper mine leading to the death of 5 people. In Kenya, a Chinese restaurant owner was accused 
of racial discrimination and labour exploitation (see Daily Nation, 2015). Chinese businessmen have also been accused of repatriating profits, doing little to help local economies recover from market shocks. We hypothesise in this paper that xenophobic tendencies in the near future will be against the invasion of Chinese into Africa.

Nevertheless, it is appropriate to mention that the cases discussed cannot be entirely generalized. In some countries in Africa, China's involvement in the national political economy has been a blessing to the local people. Mhandara and Chipaika (2013:221) observe that "availability of Chinese goods in the market and a source of income from Chinese-owned retail shops suppressed structural violence in Zimbabwe." When Zimbabwe was faced with economic hardship, Chinese investments provided economic reprieve to the impoverished population. Through the investments, infrequent goods and jobs were created much to the pleasure of the locals. To offer a further illustration of this aspect, Brautigam (2009:201) appreciates the fact that China has been instrumental in driving the industrialization agenda in some African countries. For example, he notes that China has invested in a cement plant and a woolen knitting factory in Zimbawe, a copper processing plant in Zambia and a bedding factory in Botswana. In Ghana they have funded a cocoa processing plant (Brautigam, 2009:201). It can be argued that China's contribution to Africa's industrialisation's quest has ameliorated some of the human security challenges bedeviling some African countries such as poverty and unemployment.

\section{Weapons of Death}

Africa is awash with artillery and small weapons that are either in government custody or under the guardianship of illegal groupings. China has been at the centre stage of selling these weapons. It is important to draw a caveat at this juncture that trading in weaponry does not contravene internal laws. However, the mere fact that Africa has been plagued with violent conflicts for a long period, raises academic curiosity on China's arms sell vis a vis Africa's peace and security agenda. Christophe (2005) notes that between the historical epochs 1955 - 1977, China had sold US \$ 142 million of military equipment to African countries in support of liberation movements. The supplies have increased over time. In the period 2010 - 2014, China was ranked among the world big five arms exporters that included US, Russia, Germany and France (SIPRI, 2015: 3-8). The Stockholm International Peace Research Institute (SIPRI) report of 2015 notes that China's exports of major arms had increased by 143 percent between 2005 -2014. In Africa, during the same period, China had exported arms to 18 African states. They had exported three frigates to Algeria, and a number of unmanned aerial vehicles to Nigeria (SIPRI, 2015). Other countries that have benefited from China's arms exports include Tanzania, Zimbabwe Sudan, South Africa, and Ivory Coast, among others.

The interesting link in China's arms export is that they have been used in some of the conflicts in Africa. In DRC for example, soldiers and militia groups have used Chinese made small arms to orchestrate killings of innocent civilians in the Kivus and Ituri districts (Shinn, 2009). This assertion is corroborated by a UN study that investigated the origin of 1,100 weapons collected in Ituri district. The report established that 17 percent of the weapons collected were from China. In Sudan, Chinese weapons have been used in the violence conflict in Darfur. Sudanese armed forces and Janjaweed militia group have used Chinese weapons to commit human rights abuses. A report by the UN panel charged with the responsibility of implementing arms embargo in Darfur reports 
that Sudanese Armed Forces (SAF) has used different types of Chinese ammunition against rebels. Chinese arms continue to be used in the conflict in Libya. In Liberia, Siera-Leone and Ivory Coast Chinese firms were accused of supplying weapons to rebels and mercenaries who were involved in civil war in these countries. From the cases, it is clear that Chinese arms have been used in various battlefields in Africa. We argue that the easy supply from China, despite the existing international legal regimes, further complicates some of the conflicts situations in Africa.

The accusations notwithstanding, it is imperative to mention that China has been in the forefront in helping countries in Africa improve their peace and security situation though military support and technological transfer. China has supported Nigeria with grants to modernise its military. The support has been in the form of training and intelligence gathering. The assistance to the military has been useful to Nigeria in the fight against Boko Haram. In Angola, Burundi, Mozambique, Chad, Guinea- Bissau, and Sudan, China has been pivotal in providing training for de-mining personnel and equipping them with landmine removal devices (Saferworld report, 2011: 37- 45). The efforts in de-mining have reduced the harm caused to civilians by the land-mines. Despite the positive impact of Chinese military support (hardware, human resources and technological support) the Saferworld report (2011: 42) emphasizes that:

Military training and assistance need to be delivered in the framework of wider security sector development, tied to other state institutions such as the police or the judiciary. In short, Chinese military assistance may not always be effective when isolated from broader public policy, governance and development issues that may be equally important to upholding peace and security in the long term.

The "Rogue States" and "Rogue Aid"

China's global aid portfolio and other development projects in Africa have increased exponentially in the recent past (see for example Wolfgang, 1989; Deborah, 2009; Claude, 2011). Through strategic partnership with China, Africa has continued to receive aid and other assistance totaling to billions of dollars. In 2006, for example US\$ 5 billion was pledged, in 2009, US\$ 10 billion was pledged and in 2012, US\$ 20 billion (Strange et al. 2013: 4). In 2009- 2010 for example, China Development Bank and China Export Bank provided loans amounting to US \$ 110 billion (see Dreher and Fuchs, 2011). Despite China's apparent "philanthropy", it has been accused of supporting states that have questionable human rights records thus impacting on Africa's peace and security. In the past, most western traditional donor countries such as the US, Britain, and Germany tied aid with observance of liberal democratic ideals - human rights, rule of law, credible elections among others. This implied that most African states were locked out due to their poor human rights and democracy records. With the re-emergence of China's interest in Africa, the scales have tilted. China is courting the "rogue states" without a "background check,"- as opposed to the practice cherished by Africa's traditional donors.

In a study on China's foreign aid, Dreher and Fuchs established that China's aid does not take into cognizance the democratic levels or the polity type of recipient countries (see Dreher et al 2014: 7). Roth, (2006) aptly captures it "when it comes to human rights, China's foreign policy is deliberately agnostic." Dreher and Fuchs and Roth's postulations are strengthened by a declaration from the Beijing Forum on China-Africa Cooperation 2000 that states "politicisation of human rights and imposition of human rights conditionality's on economic assistance should be 
vigorously opposed." This attitude of "see no evil and say no evil" endeared most African States, who, with much pleasure, embraced the "look east policy." With sustained support without background checks, China has propped up dictators much to the chagrin of the indigent populations. Political violence continues to be orchestrated by the dictators against perceived political opponents and civilians to secure regimes longevity and maintain state power. China has used the floor of the United Nations Security Council (UNSC) to defend some of the African leaders by either blocking or abstaining from some critical UN resolutions. For example, China abstained from voting in the UNSC when three critical resolutions - resolution 1556 - demanding for disarmament of Janjaweed militias in Darfur, resolution 1672 - imposing financial sanctions and travel restrictions on 4 Sudanese leaders and resolution 1706 - extending the mandate of UN Mission in Sudan (UNMIS) to include Darfur. These three resolutions were aimed at ending impunity in Darfur.

In Zimbabwe, despite being shirked by Europe and the United States due to its human rights records and non-compliance to the tenets of democracy, China continued to intimately engage with it. To offer a possible illustration of this aspect, Strange et al (2015: 16) observe that between 2000 and 2011, Zimbabwe had received the highest number of Chinese projects and official finance as compared to Ghana, Ethiopia and Libya. This observation is corroborated by the Mail (2013) that reports that China invested more than $£ 360$ million in 2013 and granted Zimbabwe more than $£$ 600 million in loans. China further built infrastructure facilities in Zimbabwe - schools, dams, textile factory, hospital and a national stadium, among others. In Angola, China continued to extend its largesse to the Dos Santos government, its poor human rights record notwithstanding. According to the Human Rights Watch report, 2014, Angola is a closed society characterized by restriction on freedom of expression, gagging of the media and government oppression. Given China's policy of non-interference, Angola continued to receive support from PRC despites its grim human rights record. In 2006, Angola received US \$ 4 billion and in 2010 it received an additional US $\$ 2$ billion in commodity-backed loans. It is germane to mention that these loans were geared towards oil hunt. In Sudan, China faced accusations of supporting Bashir's government despite its grim human rights abuses in Darfur. A study conducted by Nour (2014) indicates that China's financial aid, loans and grants to Sudan had increased significantly from US \$22.5 million to US \$ 66.8 million reaching a peak of US \$ 2399.3 million between the periods 1970 - 2008. The gregarious ties continued to flourish between PRC and Sudan despite Bashir's indictment by the International Criminal Court.

\section{Destruction of Fauna}

Poaching of Africa's endangered species has been on the increase in the recent past. This has been necessitated by changes that have been given impetus by modernisation. Increased urbanisation and industrialisation have destroyed habitats that provided sanctuaries for the animals. High population and advancement in technology (use of sophisticated weapons, mobile phones and GPS gargets) further compounded the problem. The Convention on International Trade in Endangered Species of Wild Fauna and Flora (CITES) estimates that 20,000 elephants had been killed in 2014 alone. According to the South African Department of Environmental Affairs, a staggering 1,215 rhinos had been killed in South Africa by end of 2014. The CITES report is poignant in its analysis, it contends that "...the number of seizures made in Africa exceeded those made in Asia. Just three 
African countries - Kenya, Tanzania and Uganda - accounted for $80 \%$ of those seizures." (See CITES, 2014 report).

The astronomical kills of elephants and rhinos and the large seizures point to the way the problem has morphed to become a peace and security challenge. Undeniably, the cumulative effects of these depredations are insecurity, corruption, and destruction of economies that largely depend on tourism as a main contributor to Gross Domestic Product (GDP). In Africa, a nexus has been established between the illicit activity of poaching and conflict. In the Great Lakes Region and Central Africa, it has been reported that illegal armed groups have continued to benefit from illegal proceeds from ivory to fuel conflict. In Congo for example, UN report (UN - S/2012/843) charges that parties to the conflict - Congolese Army, various rebel groups dotted in the Congo have benefited from illegal poaching. Proceeds from poaching have been used to perpetuate conflict in the Congo. The UN report opines:

The Congolese armed forces continue to be plagued by criminal networks generating revenue for senior officers through their control over natural resources and contraband, including the trafficking of ivory from armed groups. The Land Forces Commander, Gen. Gabriel Amisi, oversees a network distributing hunting ammunition for poachers and armed groups, including Raïa Mutomboki.

In the East Africa region a linkage between terrorist groups and poaching has been established. For example, the Al-Shaabab has been accused of sustaining itself by killing elephants and ivory poaching (International Business Times, 2014). Agger and Hutson (2013: 1-5) conjecture that the Lord's Resistance Army (LRA) uses elephant poaching to sustain its activities. According to them, "Kony orders his fighters to bring him elephant tusks which he trades for food, weapons and ammunition." The vexing issue in the poaching menace is the fact that China has closely been associated with it. China has continued to provide the demand side for poached products. A decision by the Standing Committee of the Convention for International Trade in Endangered Species in 2008 that allow a one-off sale of legal ivory and the unprecedented Chinese population in Africa seem to have exacerbated the problem. It is easy for a Chinese citizen to purchase an elephant tusk or a rhino's horn whether legal or not.

A survey conducted by Gabriel et al (2011: 3) indicates that the number of unlicensed and noncompliant ivory facilities in China far outnumber legal ones. This finding buttresses our assertion that China has continued to provide the market for Africa's fauna thus it's ravenous appetite in Africa does not potent well for Africa's security. In this case, the security of the precious fauna. An analysis of recent seizures of animal trophies trumpets Africa's worst fears. On 4 July 2013, customs authorities in Huangpu, China, seized 4,464 kg of ivory and $7.57 \mathrm{~kg}$ of rhinoceros horn. On 6 August 2013, customs authorities in Hong Kong, China, seized an illegal shipment of 2229.7 $\mathrm{kg}$ of ivory, 13 rhinoceros horns $(37.22 \mathrm{~kg}$ ) and five pieces of leopard skin (see CITES 2014). On $7^{\text {th }}$ January 2014, Police at Kamuzu international airport seized $120 \mathrm{~kg}$ of ivory destined for China (Nyasa Times, 2014). It goes without further rhetoric that China's interest in Africa remains a 
threat to Africa's animals. It's a question of time before the treasurable animals are decimated and relegated to the dustbin of history.

\section{Conclusion}

China's involvement in Africa has had both positive and negative aspects. From the positive perspective, China has contributed to Africa's economic growth by contributing to a strong commodity boom due to the upward swing in the prices of oil and metals exported by many African economies. China has also deepened trade and investment in the continent that has been marginalized in the international political economy. China is investing significantly in Africa's transport network and education infrastructure. As far as peace and security is concerned, China has invested a lot of financial resources as well as personnel in peacekeeping missions in the African continent. It is apparent from the discussions that the peacekeeping missions have been strategic in China's hegemonic quest. The simple fact that 70 percent of its peacekeeping missions are in Africa reinforces China's unrelenting interest in the continent. Through peacekeeping missions, China has been able to project itself as a reliable actor in securing world peace. On the negative, China's involvement has impacted human security aspects, impacted on wildlife population and continues to spur some of the conflicts in Africa. It is, therefore, imperative for African leaders to reassess their engagement with China. Mechanisms should be established to ensure that there are mutual benefits in the ties. China needs also to fully engage with African countries in the fight against terrorism. Terrorism is emerging as a threat to Africa's economies

and Chinese businesses in Africa. A framework should be established to ensure China's active participation in counter terrorism measures.

\section{References}

African Union Commission, 2010. African Peace and Security Architecture (APSA): 2010 Assessment Study. African Union Commission.

Agger, K. and Hutson, J. 2013. Kony's Ivory: How Elephant Poaching in Congo Helps Support the Lord's Resistance Army. Enough Project.

Agubama, E. 2014. China and Peacekeeping in Africa. International Journal of Humanities and Social Science Vol. 4, No. 11. 
Aguirre, I. 2014. Violence in South Sudan Threatens Chinese Oil Investment. Available at http://oilprice.com/Energy/Crude-Oil/Violence-In-South-Sudan-Threatens-Chinese-OilInvestment.html. Retrieved on $24^{\text {th }}$ June 2015.

Ahmed, K. G. 2010. The Chinese Stance on the Darfur Conflict. Occasional Paper No. 67. South Africa Institute of International Affairs.

Ateba, B. 2002. Is The Rise Of China A Security Threat? Polis / R.C.S.P. / C.P.S.R. Vol. 9, Numéro Spécial.

Ayenagbo, K, Njobvu, T, Sossou, J. V. and Tozoun, B. K. 2012. China's Peacekeeping Operations in Africa: From unwilling Participation to Responsible Contribution. African Journal of Political Science and International Relations Vol. 6(2), pp. 22-32

Bank Working Paper Number 129. Tunis, Tunisia: African Development Bank.

Bates, F. 2009. China and the Issue of Peacekeeping. Green Press, Hong Kong China.

Bernstein, Richard and Ross Munro (1997), the Coming Conflict with China, New York: Alfred A. Knopf.

China Military News, 2015. UN awards medals to Chinese peacekeeping troops in Darfur, Sudan. Available at http://english.chinamil.com.cn/news-channels/china-military-news/201512/11/content_6812737.htm. Retrieved on 24 ${ }^{\text {th }}$ May 2015.

Chipaika, R. and Mhandara, L. 2013. "Evading Punishment: An Analysis of Zimbabwe - China Relations in an age of Sanctions." In Mulegeta, G. B. and Liu Hongwu (Ed.) 2013.China-Africa Relations: Governance, Peace and Security. Addis Ababa. Institute for Peace and Security Studies

Christophe J. S. 2005. 'China’s Trade Safari in Africa' in Le Monde Diplomatique, May 2005;

Claude, J. B. 2011. China's Engagement and Aid Effectiveness in Africa. African Development

Daily Nation "Only 'loyal' African Patrons are allowed in Chinese Restaurant after Sunset" 23 rd March 2015.

Deborah B. 2009. The Dragon's Gift: the Real Story of China in Africa. Oxford, UK: Oxford University Press.

Dreher A, Fuchs A, Hodler R, Parks C. B, Raschky A. P, and Tierney J. M. 2014. Aid on Demand: African Leaders and the Geography of China's Foreign Assistance. Working Paper No. 3.

Dreher, A and Fuchs A. 2011. Rogue Aid? The Determinants of China's Aid Allocation.. Germany: Goettingen 
Dreher, A. and Fuchs A. (Forthcoming.) Rogue Aid? An Empirical Analysis of China's Aid Allocation. Cited in Dreher A, Fuchs A, Hodler R, Parks C. B, Raschky A. P, and Tierney J. M. 2014. Aid on Demand: African Leaders and the Geography of China's Foreign Assistance. Working Paper No. 3.

Gabriel, G. G, Hua N and Wang J. 2011. Making a Killing: A 2011 Survey of Ivory Market in China. International Fund for Animal Welfare.

Gordon, D. 2011. Chinese Juggernaut? China's Rapid Growth Is a Legitimate Worry for Leaders in Washington and Beijing. Cited in Zhou, J. 2011. American Perspective versus Chinese Expectation on China's Rise. International Journal China Vol. 2 No. 3, pp. 625-645.

Grasper, D and Truong, T. 2005. Deepening Development Ethics: From Economic to Human Development to Human Security. The European Journal of Development Research 17(3) 372-384.

Hang, Z. 2014. China and South Sudan: economic engagement continues amid conflict. Available at http://africanarguments.org/2014/09/12/china-and-south-sudan-economic-engagementcontinues-amid-conflict-by-zhou-hang/. Retrieved on $24^{\text {th }}$ June 2015.

Huang, C. and Gill, B. 2009. China's expanding peacekeeping Role. SIPRI. Available at http://www.sipri.org/media/newsletter/essay/jan09. Retrieved on 24th June 2015

Human Rights World Report 2014.

International Business Times "White Widow Samantha Lewthwaite Linked to Ivory Poaching" $13^{\text {th }}$ January 2014.

IRI. 2015. Southern Africa: Increasing Hostility towards Chinese Traders. Available at http://www.irinnews.org/report/96266/southern-africa-increasing-hostility-towards-chinesetraders. Retrieved on $6^{\text {th }}$ June 2015

Junbo, J. 2012. China in International Conflict Management: Darfur as a Case. Available at http://www.google.com/url?sa=t\&rct=j\&q=\&esrc=s\&source=web\&cd=1\&ved=0CCAQFjAA\&u $\underline{\mathrm{rl}=\mathrm{http} \% 3 \mathrm{~A} \% 2 \mathrm{~F} \% 2 \mathrm{Fwww} . \text { saferworld.org.uk\%2Fdownloads\%2Fpubdocs } \% 2 \mathrm{FJian}-}$ Junbo.pdf\&ei=s--LVbGXHYjZQH4j73IBg\&usg=AFQjCNGWfArXqTxZWZkwaot6PFbinRJ3yw\&sig2=oYlw_aMN5TLKBdE OaBZlHA\&bvm=bv.96782255,d.cWw\&cad=rjt. Retrieved on $25^{\text {th }}$ June 2015.

Kaplan, R.2005. How We Would Fight China. Atlantic Monthly, 28 April.

Mail 'China welcomes its 'old friend' Robert Mugabe with a 21-gun salute, as Zimbabwean leader seeks cash to bail out ailing economy. $26^{\text {th }}$ August 2014.

Mearsheimer, J. 2011. The Rise of China Will Not Be Peaceful at All. Cited in Zhou, J. 2011. American Perspective versus Chinese Expectation on China's Rise. International Journal China Vol. 2 No. 3, pp. 625-645. 
Miner, Y. 2007. Downside Risks and Human Development/Security. Cited in Akokpari J. 2007. The Political Economy of Human Insecurity in Subsaharan Africa. Institute of Development Economies. No. 436

Ministry of Commerce of the People's Republic of China. 2014. 2013 Statistical Bulletin of China's Outward Foreign Direct Investment. Beijing, China: China Statistics Press

Ministry of Defense 2008. Chinas 2008 White Paper on Defense. Beijing

Moumouni, G. 2014. China and Liberia: Engagement in a Post-Conflict Country 2003-2013. Occasional Paper No. 182. South Africa Institute of International Affairs

Nour S.S O. M. 2014. Assessment of Effectiveness of Chinese Aid in Competence Building and Financing Development in Sudan. UNU-MERIT Working Papers January 2014.

Nyasa Times “Malawi Police Intercept $120 \mathrm{~kg}$ of Ivory destined to China” $7^{\text {th }}$ January 2014

Reuters "Chinese team arrives in Liberia to staff Ebola clinic" 16 $6^{\text {th }}$ November 2014.

Roth, K. 2006. "China's Silence Boost Tyrants" as Cited in Ufodile, U. 2009. Trade, Aid and Human Rights: China's Africa Policy in Perspective. Journal of International Commercial Law and Technology Vol. 4, Issue 2.

Safer world Report (2011) China's growing role in African peace and security. Saferworld.

Shinn, D. 2009. Chinese Involvement in African Conflict Zones. China Brief: 9 Issues 7. Available at

http://www.jamestown.org/programs/chinabrief/single/?tx_ttnews[tt_news]=34792\&cHash=176 $557 \mathrm{~b} 3 \mathrm{a} 2$. Accessed on $25^{\text {th }}$ June 2015

Strange A, Parks B, Tierney M J, Fuchs A, Dreher A, and Ramachandran V. 2013. China's Development Finance to Africa: A Media-Based Approach to Data Collection. Working Paper 323. Center for Global Development.

Strange, M. A, Parks, B, Tierney, J. M, Fuchs A, Dreher, A. 2015. Tracking Under-Reported Financial Flows: China's Development Finance and the Aid-Conflict Nexus Revisited. Germany. Goettingen.

Taylor I. 2015. “Beijing's Arms and Oil Interests in Africa”. In China Brief, Volume 5 Issue 21, 2015.

The Stockholm International Peace Research Institute (SIPRI). 2015. Trends in International Arms Transfers, 2014. SIPRI Facts Sheet available at http://books.sipri.org/files/FS/SIPRIFS1503.pdf. Retrieved on 22nd June 2015 
United Nations Security Council Report (2012) Available at http://www.securitycouncilreport.org/atf/cf/\%7B65BFCF9B-6D27-4E9C-8CD3CF6E4FF96FF9\%7D/s_2012_843.pdf. Retrieved on 10th June 2015

Van de Looy, J. 2006. Africa and China: A strategic Partnership. ASC Working Paper No. $67 / 2006$.

Wolfgang, B. 1989. The Economic Aid of the PR China to Developing and Socialist Countries, 2nd ed. Munich, Germany: K. G. Saur.

World Food Programme (2014) China Contributes US\$6 Million To WFP In Fight Against Ebola In Guinea, Liberia \& Sierra Leone. Available at https://www.wfp.org/news/news-release/chinacontributes-us6-million-wfp-fight-against-ebola-guinea-liberia-sierra-leone. Retrieved on $26^{\text {th }}$ June 2015

Zeleza, P. T. 2008. Dancing with the Dragon: Africa's Courtship with China. The Global South. Vol. 2, No. 2.

Zhou, J. 2011. American Perspective versus Chinese Expectation on China's Rise. International Journal China Vol. 2 No. 3, pp. 625-645. 